International Journal of English Language Studies (IJELS)

ISSN: 2707-7578

DOI: 10.32996/ijels

Website: https://al-kindipublisher.com/index.php/ijels

\title{
Construction of Reality in Pakistani English Newspapers: A Semiotic Analysis Study
}

Awais Rubbani ${ }^{1 *}$, Robina Sarwar ${ }^{2}$, and Rabia Ghaffar ${ }^{3}$

${ }^{1}$ Lecturer of English, Government College University Faisalabad, Pakistan

${ }^{23}$ Lecturer of English, Riphah University Faisalabad Campus, Pakistan

Corresponding Author: Awais Rubbani, E-mail: awaisrubbani786@gmail.com

\section{ARTICLE INFORMATION}

Received: December 17, 2020

Accepted: February 10, 2021

Volume: 3

Issue: 2

DOI: 10.32996/ijels.2021.3.2.4

\section{KEYWORDS}

Newspaper Cartoons, Social Satire, Barthes Model, Rhetorical Device

\section{ABSTRACT}

Representation of social issues of the society through cartoons is of great importance in Pakistan. The newspapers' cartoonists represent social issues according to their own objectives. They construct satire on these social issues by using images and captions. It is significant to investigate how the newspapers' cartoonists frame reader's opinion about social issues of the society through linguistic choices. The current study was conducted to examine social satire in cartoons in Pakistani English newspapers. The objectives of the current research were to identify the recurring social themes in cartoons, to investigate the semiotic devices used in cartoons and to find out the logical connection developed between linguistic and semiotic devices in cartoons for the reflection of social issues in Pakistani English newspapers. The present research was qualitative in nature. The data were collected from the cartoons published in Pakistani English newspapers i.e. Daily Times (Pakistan), Dawn and The Nation. Barthes' (1974) model of semiological analysis was used for interpretation of social satire in cartoons in Pakistani English newspapers. After analysis, it was found that the newspaper's cartoonists used specific linguistic devices like exaggeration, symbolism, labeling, caption, irony and analogy for construction of social satire in cartoons. They also exposed the social issues like corruption, inflation, explanation, terrorism, poor democracy, wrong policies of the government, thana culture, energy crises, meat adulteration and child brutality. There were also logical connections between linguistic and semiotic devices in cartoons to enhance the reader's understanding of social satire.

\section{Introduction}

Semiotics (semiology) was first employed by the Swiss linguist Ferdinand de Saussure in the early twentieth century. As the study of semiology is connected with the common properties of signs and other signal forms, semiotics deals with science of signs that allowed the production of a number of viewpoints and lined the way to various cultural events that elevated the study of signs in the course of its connotative and denotative meanings.

After getting inspiration from the concept of de Saussure, linguists began to develop new theories of different kinds of signs and its connotative meanings. Roland Barthes was a key player in the French school structuralism semiotics. He developed his approach in denotation and connotation in relation to photographic images as a system of signs. Barthes (1974) claimed that image has two layers: of what and how it is represented. He clearly described that denotation is concrete while connotation is more complex and abstract concept.

With the advancement of semiotics, the media has become a leading communication network that appeals broader community attention using language as an instrument of stating views and thoughts from a specific point of view. This particular feature of language use has made media discourse a practicable and powerful research field. The media plays a significant part in our daily life; it affects us through its different functions and occupies an important part for most people. Linguists over the years have been studying how language is precisely used in different genres to complete communicative tasks. With the study of media language, there has been a substantial research output on cartoons interested in domestic issues across academic disciplines

K C AL-KINDI CENTER $R$ FOR RESEARCH AND $R$ D DEVELOPMENT Your gateway to world-class research

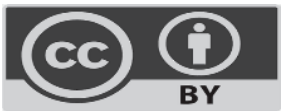

Published by Al-Kindi Center for Research and Development. Copyright (c) the author(s). This open access article is distributed under a Creative Commons Attribution (CC-BY) 4.0 license 
over the recent years. The increasing interest indicates that cartoons have successfully constituted a distinct multimodal genre within media discourses. Beyond humor, cartoons are crafted to 'bury' the true meanings, and hide the cartoonists' true proposed meanings that represent their logical meaning.

In cartoons, many researchers did work and even a lot of researchers are working on semiotic analysis of cartoons, newspapers and advertisements. Stone (2000) did work on a semiotic analysis of four commercials by employing the two basic theories of semiotics i.e. Ferdinand de Saussure and Peirce theories and resulted that semiotic analysis of commercials was useful for comprehension the basic meanings and object of the adverts. Zheng (2013) also conducted a research on semiotic analysis of a print poster of coca cola bottle and resulted that semiotics gave guideline to the promoters to select according to their requirements and needs and it showed victorious to draw the consumers and made the merchandise publically up to standard. Cartoon is a diagram medium that connects the reader, assists them to understand and interpret the political, social and economic scene in the country. Editorial cartoon has an old tradition of integration of social satire in a society. Cartoons in Pakistani English newspapers reflect present social problems of our society. Apparently, cartoons are supposed to be very simple, but they influence the minds of the reader about social issues of the society. This area had not been explored appropriately yet. So, there was a need of semiotic analysis of the cartoons in order to explore the linguistic and semiotic devices employed by the cartoonists to reveal their objectives. To materialize the objectives of the current research, following research questions were posed.

1. What are the recurring social themes in cartoons for the reflection of social issues in Pakistani English newspapers?

2. What are the semiotics devices which have been used in cartoons for the reflection of social issues in Pakistani English newspapers?

\section{Literature Review}

Satire is a form of humor which is used to express a subject or a person in humoristic behavior. Its aim is to indicate prevailing vices or follies (through humor) which should be corrected. In other words, we can say that satire is a mixture of criticism and humor in order to change that which looks wrong.

According to the Dictionary of Literary Terms (1977) social satire is a fictional work planned to provoke ridicule, scorn and follies of man and his institutions. It is also aimed at correcting misconduct by inspiring both annoyance and laughter with a mixture of wit and. The notion of satire is originated from the act of scorn or ridiculous, to right the harms of the society. Satire is any piece of writing that uses devices such as irony. Social satire is a fact or situation that has the cause of making some person or thing ridiculous. It is engaged to mock or reason the actions of man or his beliefs.

Social satire can be illustrated as the literary art of distinguishing a subject by making it ridiculous and evoking toward it attitudes of amusement, scorn, contempt, or indignation. It differs from the comic in that comedy evokes amusement chiefly as an end in itself, while satire ridicules and it uses laughter as a weapon, and against a bump that exists outside the work itself. Usually, satire has been justified by those who apply it as a reform of human voice and folly. It's mostly claim has been to scorn the failing rather than the entity, and to bound its scorn to corrigible errors, exclusive of those for which a person is not liable.

Satire happens as an incidental part within a lot of works whose generally mode is not satiric in a definite character or condition, or in an exclaimed passage of ironic explanation on some characteristic of the human situation or of current society. But for some literary scripts, prose or verse, the effort to reduce a subject by scorn is the main organizing rule, and these works comprise the proper genre labeled "satires."

According to Kimani (2013) observation, satire is a "militant irony" that has two basic features. First, anger is a crucial constituent of satire. In reality, satire is an assault. Second, Kimani (2013) viewed irony as satire's weapon of choice. He further stressed that irony is itself a dialogic link. By using irony, satirists appeal to interpreters to reshape the connotation of a word in view of its new context. They suppose their readers to make the essential outside connections. Satire is dialogic in at least two ways. First, it submits to another text, which is the subject of the critique. Second, it depends on the viewers to study it as satire. As a result, $\mathrm{Njogu}(2006)$ contrasted parody and satire, stating that satire, like parody, is associated to the carnival sense of the world.

In these two genres, the world is twisted inside out because satire depends mainly on the interpreter's capability to identify that the indirect secret expression is in reality an assault with definite goals, it is an undecided genre. But the suitable set of principles against which our failings can be eager to form the baseline of satire has frequently been the point of disappearance between the satirist and his critic. 
As a literary manner, social satire is linked with mocking human and institutional follies with the objective of reforming them. Social satire may be shown in the form of allegory and also form of imitation through caricatures and pictures, it is dangerous treatment of subjects in a theatrical fashion, also in the form of Lampoon which is defined as the act in which an individual is shown in a dangerous way, and this makes it a subject of amusement. In the form of irony which is defined as a situation whereby the proposed meaning is the opposite of that indicated by the word used. Abrams M. H. (1991) says: "Social satire is the literary art of diminishing a subject by creating it preposterous and suggesting towards, its approach of laughter, indignation, scorn or contempt."

For him, social satire is a scorn going to making an individual or society less as a consequence of the subject's folly, laughter and without due value of the subject Abrams definition of social satire only out to scorn alone and not to reform in as much as satire mocks. It also reforms or moves the subject away from his or her foolishness and harms separately from just being amusing. Although it employs amusement as weapon to scorn, unlike comedy that suggests amusement chiefly as an end in itself the same amusement could also be used to reform harms of the subject.

The view of Margaret Dable (1992) on satire is "... a poem, or a prose work, in which existing vices or follies are held up to scorn". Like Abrams and Emeaba, Margaret Dable considers that the purpose of social satire is merely out to scorn the follies of an individual or the society, either written in poetry or in the type of prose. She fails to disclose the other feature of satire that is satire is a double-edged sword. It scorns, amuses through humor and at the same time reforms the folly and forms the individual in the society. Satire is a variable term.

Samuel Johnson (1921) views that satire is a poem in which badness or censured. Like the earlier scholar, Johnson is of the view that satire tricks or scorns the folly of the individual. All the researchers are of the view that social satire is an art that mocks the folly of the individual and society, and when the plans from the customs of his traditions or society. Not all researchers consent on the notion that social satire also reforms and forms the individual in the society. In conclusion, with all these researchers' view, we can say that social satire is a form of discourse, either in prose or poetry, which creates fun of the foolish or ills behavior of people, society or institutions in general. In other words, the purpose of social satire is not just to criticize, but also to correct the society.

Wole Soyinka (1963) is an author whose attention is a disclosing in depth the socio-political condition of the African society. His works concentrate on examining the nature of his society. For him, a playwright should be a dream of his people, one who will go all the way to plan a purposeful future for his people. By examining the society, Soyinka aims to make the society come to conditions with the nature of their troubles which are a crucial step towards resolving the issue.

Cartoon is a significant and essential part of our societal culture. Comedic, expressive and sometimes political, cartoon appeals to all people both adults and children. "Cartoon" is originated from the Italian word "cartone" which stand for "large paper". In its simplest appearance, cartoons are big, graphic images that provide the purpose of describing a story or remarking on a political or social problem. Simultaneously, one question occurs into our minds: what makes cartoons so effectual in spite of their simplicity? According to Pulitzer Prize winning author and cartoonist Art Spiegel man,

"Comic is the technique brain think. You have small groups of words in the brain when you speak to somebody. These groups become iconic, abstracting images representing a visual that becomes real in your mind".

It is significant to know the beginning of cartoons and how they have developed over the centuries to entirely appreciate the animations and cartoons that are shaped today. With this information comes the comprehension that little has changed in the purpose cartoons serve. The cartoon communication in Pakistan had been flourished during military regime of General Zia ul Haq (1977- 1988) of Pakistan which was considered as the era of black laws. There was little press liberty. During that period, a well-known political cartoonist, identified as Nanha, begun to criticize the government's black laws through his cartoons, His cartoons were light in tone but delivered much required mockery for government actions. Later on, many cartoonists like Javed Iqbal, Maxim, Feica, Shahtoon, Nigar Niazi, and Zaidi etc, have been working as political cartoonists in the mainstream newspapers of Pakistan but unfortunately, Pakistani scholars and thinkers did not pay attention on this medium as in the whole world. In Pakistan, the research on social and political cartoons is limited. But now it is thought that social and political cartoons can play a significant role as an important platform of propaganda as the Danish newspapers used this means to criticize the Holy Figure of Muslims. Cartoonists set agendas according to the editors, pressure groups, and their individual interests. But on the other side, there is also supposition that people get this medium as only for amusing and satire to make audience chuckle without any agenda. 
Tahreem (2013) tried to investigate face saving and face spoiling in Pakistani political cartoon. According to her, the newspapers cartoonists purposefully designed political cartoon to expose or hide their identities. Saussure (1974) presented a 'dyadic' or two-part model of the sign. He stated a sign as being made of a 'signifier' (signifiant) shows the form which the sign takes and the 'signified' (signifié) shows the concept it symbolizes. The sign is the complete that consequences from the relationship of the signifier with the signified. The association between the signifier and the signified is mentioned to as 'signification', and this is symbolized in the Saussurean diagram by the arrows. A sign must have both a signified and a signifier. We cannot have a completely formless signified or a completely meaningless signifier. A sign is a recognizable mixture of a signifier with a signified. The similar signifier could set for a dissimilar signified. In the same way, many signifiers could stand for the different concept.

\section{Methodology}

The present research was a semiotic analysis of cartoons published in Pakistani English newspapers. The objectives of the current research were to identify the recurring social themes in cartoons, to investigate the semiotic devices used in cartoons, and to find out the logical connection developed between linguistic and semiotic devices in cartoons for the reflection of social issues in Pakistani English newspapers. The present research was qualitative in nature. Barthes' (1974) model of semiological analysis was used for interpretation of social satire in cartoons in Pakistani English newspapers. Barthes' (1974) model of semiological analysis was the latest model in the field of semiotics. This model was also suitable for present research. The current research was based on qualitative approach. The data were collected from the cartoons published in Pakistani English newspapers i.e. Daily Times (Pakistan), Dawn and The Nation. Barthes' (1974) model of semiological analysis was used for interpretation of social satire in cartoons in Pakistani English newspapers. The population of the current study was all the Pakistani English newspapers. The sampling was made representative by selecting twenty images of cartoon of three Pakistani English Newspapers i.e. The Nation, Dawn and Daily Times (Pakistan). These newspapers were selected for data collection due to their high ranking of publication.

\subsection{Data Analysais}

In the current research, twenty images of cartoons were selected for semiotic analysis. Barthes' (1974) model was employed to analyze these cartoons critically. The identification of signs, their meaning and types of the signs were presented in a table. The research was conducted on the following two levels of Bathes' (1974) model:

\subsubsection{The Denotative level of the image}

Denotative level interpretation deals with the recognition and type of the signs on surface level of the meanings. In the present research, at denotative level, physical appearance of the signs was identified and described.

\subsubsection{The Connotative level of the image}

Connotative level interpretation deals with the literal and implied meanings of the whole message. In the present research, at connotative level, implied meanings of the sings were explored and analyzed in the socio-political context of Pakistan.

\section{Results and Discussion}

The present research was based on semiotic analysis of cartoons published in Pakistani English newspapers. The present research was qualitative in nature. The data were collected from the cartoons published in Pakistani English newspapers i.e. Daily Times (Pakistan), Dawn and The Nation. Barthes' (1974) model of semiological analysis was used for interpretation of social satire in cartoons in Pakistani English newspapers. The data were analyzed at two levels i.e. the denotative level and the connotative level. Denotative level dealt with the identification and type of the signs on surface level, while connotative level dealt with the literal and implied meanings of the whole message.

\subsection{Analysis of Cartoon image}

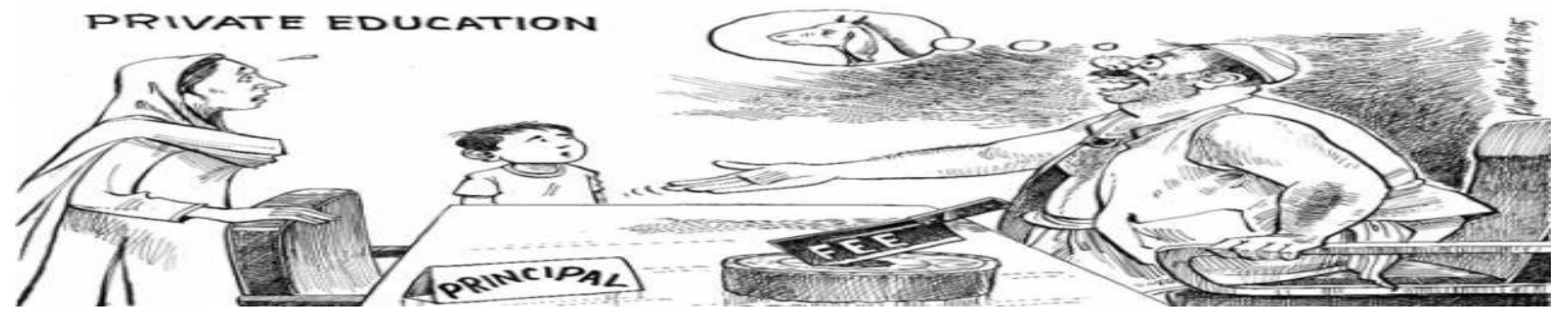

Image 4.1: Private education, Daily Times, 16-09-2015 
This cartoon is a satire on social evil "cruel behavior of private education in the shape of high fees." After identification of signs in the image, its types and the denotative and connotative meaning of signs have been presented in the below table.

Table 4.1 Identification, Meaning and Types of the Signs

\begin{tabular}{|c|c|c|c|}
\hline No. & Identification of sign & Denotative meaning of sign & $\begin{array}{l}\text { Connotative meaning } \\
\text { of sign }\end{array}$ \\
\hline 1 & The label & Private Education & $\begin{array}{l}\text { Private education } \\
\text { getting unfair profit, } \\
\text { cruel attitude of private } \\
\text { education }\end{array}$ \\
\hline 2 & The mother's eyes and nose & Stare and aciform & $\begin{array}{l}\text { Show her agape and } \\
\text { astonish after meeting } \\
\text { the principal in the } \\
\text { shape of butcher }\end{array}$ \\
\hline 3 & The mother's mouth & Widely open & $\begin{array}{l}\text { Shows her } \\
\text { embarrassment after } \\
\text { meeting the principal in } \\
\text { the shape of butcher }\end{array}$ \\
\hline 4 & The children's eyes and nose & Stare and flat & $\begin{array}{l}\text { Show his agape and } \\
\text { astonish after meeting } \\
\text { the principal in the } \\
\text { shape of butcher }\end{array}$ \\
\hline 5 & The children's mouth & Widely open & Shows surprised \\
\hline 6 & The principal's dress & Dhoti and waste-coat & $\begin{array}{l}\text { Shows principal in the } \\
\text { shape of butcher }\end{array}$ \\
\hline 7 & $\begin{array}{l}\text { The specific articles- "Burdah } \\
\text { and Mudi" }\end{array}$ & A tool is used to slaughter client & $\begin{array}{l}\text { Graving money with } \\
\text { cruelty }\end{array}$ \\
\hline 8 & The caption & Goat & Client looks a prey(goat) \\
\hline
\end{tabular}

4.1.1 The Denotation Level of the Image

There are three persons in this picture a child, mother of a child and a principal. Mother is wearing a very simple dress. A child has also simple dress. A principal is having a very strange dress like "dhoti and open waste coat". His mouth is open, he has flat nose and bulging eyes. The things which are on the principal's table are "Mudi and Burdah". Principal warmly welcomes his client and says to sit on chair with his hand's notion.

4.1.2 The Connotation Level of the Image

At connotative level, the label "private education" indicates the cruel attitude of the private education. This education system is busy to get unfair profit from the parents. In our society, private institution has gained much importance for providing reasonable education to the children. But now-a-days, they are commercialized. In this image, the clients (mother and children) are present in the office of the principal. Their face expressions express embarrassment and astonishment on the welcome of principal. On seeing 
his clients, his mind thinks about his prey (goat). The sign of goat in the caption indicates the mindset of the principal. It also indicates the lust and greed of administration of private education. The articles (burdah and mudi) in the shape of high fees indicate the cruelty of private education. Their aim is to just get money from the children of the parents. Private education institutions get money by adopting fowl or fair means. Due to high fees, the parents are looked embarrassed in our society. They are worried about education expenses of their children. On the other hand, the principal who is wearing butcher's dress indicates his cruelty like butcher man. The physical shape of the principal also points out his lust of something. In this image, high fees show as "the Burdah and Muddi" to slaughter the parents. The principal's room presents as butcher shop, where the people are treated as prey (goat) instead of parents.

\subsection{Analysis of Cartoon image}

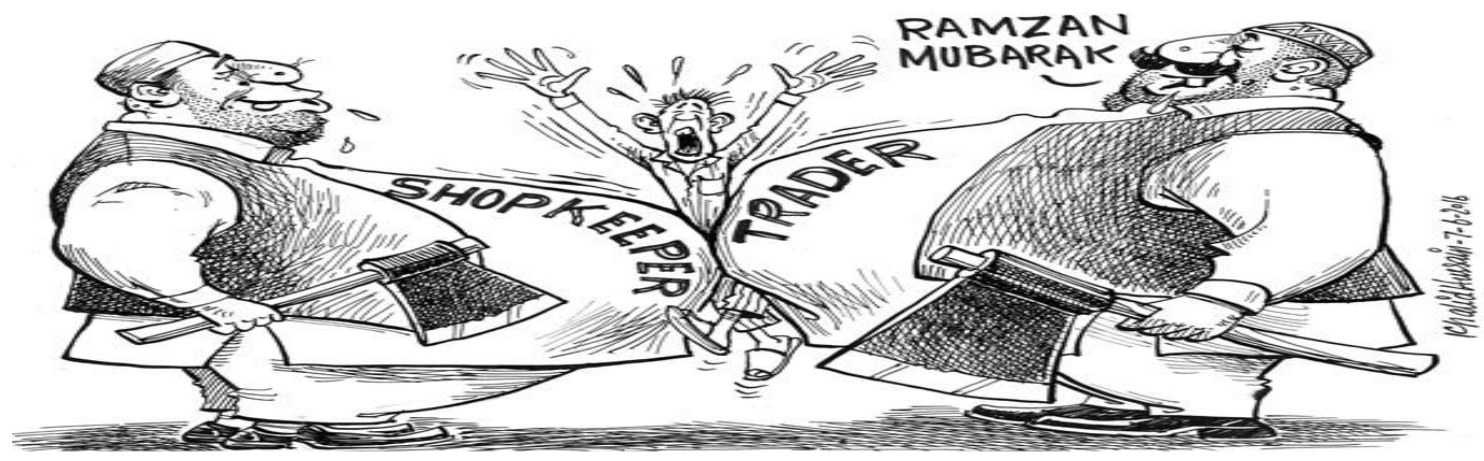

Image 4.2: Ramzan Mubarik, Daily Times, 07-06-2016

This cartoon is a social satire on "price hiking" on the coming of the holy month "Ramzan". After identification of signs in the image, its types and the denotative and connotative meaning of signs have been presented in the below table.

Table 4.2 Identification, Meaning and Types of the Signs

\begin{tabular}{|c|c|c|c|}
\hline No. & Identification of sign & $\begin{array}{l}\text { Denotative meaning of } \\
\text { sign }\end{array}$ & Connotative meaning of sign \\
\hline 1 & Label & Ramzan Mubark & $\begin{array}{l}\text { The holy month is not pleasant } \\
\text { month for public in social } \\
\text { reality }\end{array}$ \\
\hline 2 & The trader's nose & Bulging & Shows his humiliation \\
\hline 3 & The trader's lips & Large & $\begin{array}{l}\text { Show happiness on coming the } \\
\text { month of looting i.e. Ramzan }\end{array}$ \\
\hline 4 & The trader's eyes & Closed & $\begin{array}{l}\text { Show excitement on coming } \\
\text { the month of making money } \\
\text { i.e. Ramzan }\end{array}$ \\
\hline 5 & The trader's body & Healthy and chubby & $\begin{array}{l}\text { Shows overwhelming, lust and } \\
\text { greed in the month of Ramzan }\end{array}$ \\
\hline 6 & The trader's dress & $\begin{array}{l}\text { Shalwar kameez and waist } \\
\text { coat }\end{array}$ & Shows business class \\
\hline 7 & The shopkeeper's nose & Bulging & Shows his humiliation \\
\hline 8 & The shopkeeper's lips & Large & $\begin{array}{l}\text { Show happiness on coming the } \\
\text { month of looting i.e. Ramzan }\end{array}$ \\
\hline 9 & The shopkeeper's eyes & Closed & $\begin{array}{l}\text { Show excitement on coming } \\
\text { the month of making money } \\
\text { i.e. Ramzan }\end{array}$ \\
\hline
\end{tabular}




\begin{tabular}{|c|c|c|c|}
\hline 10 & The shopkeeper's body & Healthy and chubby & $\begin{array}{l}\text { Shows overwhelming, lust and } \\
\text { greed in the month of Ramzan }\end{array}$ \\
\hline 11 & The shopkeeper's dress & $\begin{array}{l}\text { Shalwar kameez and waist } \\
\text { coat }\end{array}$ & Shows business class \\
\hline 12 & The man & A human being & $\begin{array}{l}\text { Shows as purchaser, public and } \\
\text { common person }\end{array}$ \\
\hline 13 & The man's eyes & Closed & $\begin{array}{l}\text { Show pain which bear in the } \\
\text { shape of inflation on the } \\
\text { coming of holy month i.e. } \\
\text { Ramzan }\end{array}$ \\
\hline 14 & The man's mouth & Widely open & $\begin{array}{l}\text { Cry due to inflation on the } \\
\text { coming of holy month i.e. } \\
\text { Ramzan }\end{array}$ \\
\hline 15 & The man's hands & Standing due to pain & $\begin{array}{l}\text { Show helplessness in front of } \\
\text { inflation in the month of } \\
\text { Ramzan }\end{array}$ \\
\hline 16 & The man's dress & Shalwar kameez & Shows poverty and poor class \\
\hline 17 & The cutter & $\begin{array}{l}\text { A tool used to cut } \\
\text { something }\end{array}$ & $\begin{array}{l}\text { Used to grave money with } \\
\text { cruelty }\end{array}$ \\
\hline
\end{tabular}

\subsubsection{The Denotation Level of the Image}

There are three persons in this picture a shopkeeper, a trader and a man (citizen). Both the shopkeeper and the trader are wearing a business class dress. The size of their faces and bellies shows their good health. Both have bulging eyes. Both wear the holy cap on their heads. Both are in happy mode and wish the holy month of the Muslims "Ramzan". On this occasion, they have a large cutter in their hands to kill someone. On the other side, a man wears old and worn dress. His face and belly size are very weak. Instead to welcome the holy month "Ramzan" he cries loudly by opening his mouth.

\subsubsection{The Connotation Level of the Image}

At connotative level, the label "Ramzan Mubarak" indicates the holy month as unpleasant month for public in social reality. The month of Ramzan is a holy month for all Muslims of the world. On coming of this month, the prices of the basic commodities are decreased in respect of this month and to give relief to the public. But in our society, this is completely opposite. In this image, both characters trader and shopkeeper indicate this reality beautifully. The bulging noses of shopkeeper and trader expresses the humiliation. Their open lips and ironic smiles disclose their happiness on coming the month of looting. These signs indicate their thinking for this holy month. This month is a month of making money for them instead of the month of blessing. Their healthy and chubby bodies indicate their overwhelming, lust and greed in the month of Ramzan. Their dresses reveal that they are belonged to business class which shows their business mindset. They are concerned only their profit. Their holy caps disclose that they have religious faith. On the coming of this month, they become religious persons by wearing the holy caps. Along with the holy caps, they have cutter in their hands. A cutter expresses their cruelty in the form of price hiking. With this cutter they are ready to slaughter the common man. In this image, a man shows a common person of the society. His closed eyes show his pain which he bears in the shape of inflation on the coming of holy month Ramzan. His open mouth indicates his sob due to inflation on the coming of holy month Ramzan. His standing hands show his helpless in front of price hiking which produces by the trader and the shopkeeper. His thin body and old dress show his poverty and the problem of basic necessities due to inflation. In this way, a cartoonist beautifully presents how a month of Ramzan is become a month of distress for a common person in our society. This image shows a social satire on the business class i.e. a trader and a shopkeeper. For getting unfair profit, they are creating artificial shortage of things and increase the prices of the things. On this occasion, they forget their religious believes as well. 


\subsection{Analysis of Cartoon image 4.3}

\section{HEALTH, EDUCATION GOVT'S TOP PRIORITIES- PUNJAB MINITER}

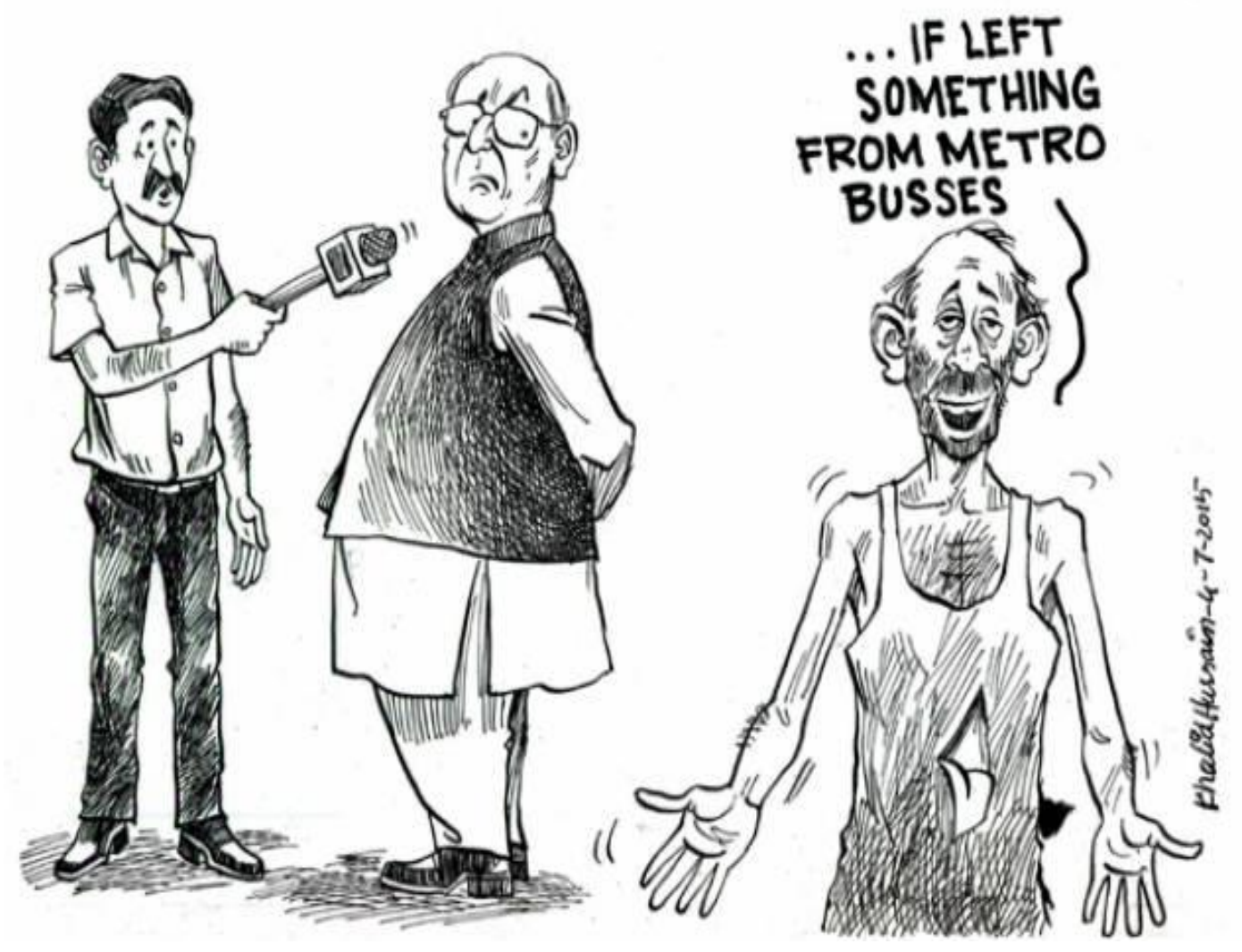

Image 4.3: Health, Education Govt's Top Priorities, Daily Times, 04-07-2015

This cartoon is a social satire on misdirection of budget allocation of the Punjab Government. After identification of signs in the image, its types and the denotative and connotative meaning of signs have been presented in the below table.

Table 4.3 Identification, Meaning and Types of the Signs

\begin{tabular}{llll}
\hline No. & Identification of sign & Denotative meaning of sign & $\begin{array}{l}\text { Connotative meaning } \\
\text { of sign }\end{array}$ \\
\hline 1 & The label & $\begin{array}{l}\text { Health, education govt's top } \\
\text { priorities }\end{array}$ & $\begin{array}{l}\text { The main priority of } \\
\text { present government is } \\
\text { metro project and it } \\
\text { neglects the basic } \\
\text { needs of a common } \\
\text { man i.e. health and } \\
\text { education }\end{array}$ \\
& & $\begin{array}{l}\text { Seriousness and } \\
\text { suspense }\end{array}$ \\
2 & $\begin{array}{l}\text { The eyes, nose and face of the } \\
\text { reporter }\end{array}$ & Opened, flat and sad & Employee class \\
4 & The reporter's dress & Pent and shirt & Show his irritation
\end{tabular}


6

7

8

9

10

11 The man's body

12

The mic

13

The man's eyes

The man's lips

The caption
The Punjab Minister's face

The Punjab Minister's dress

The man's hands

The man's short beard
Healthy

Shalwar kameez and waist coat

Opened

Closed

Opened

Old man

Half naked and skinny

A tool

Question
Shows his anger and

tension

Politician class

Tired, exhausted

Show his sadness

Questioning, upset, languid

Neglected

Lack of basic facilities, starvation

Interview

To be sure

4.3.1 The Denotation Level of the Image

There are three persons in this picture a reporter, a Punjab minister and a man (citizen). The reporter is wearing a pent shirt. He has a mick in his hand. The P.M. is wearing a business class dress. He looks like a chubby person. He gives comments to the reporter that "Health, Education Govt's Top Priorities". The man wears an old and worn dress. He has a weak phasic. He has not been shaving, which is obvious from his beard. On hearing the comment of the Prime minister, he opens his hands to show his helplessness and languid and thinks that "....If left something from Metro buses". On the reaction, the P.M. turns his face from the reporter towards the man.

\subsubsection{The Connotation Level of the Image}

At connotative level, the label "Health, Education Govt's top priorities" indicates that the main priority of present government is "Metro Buses Project" and it neglects the basic needs of a common man i.e. health and education. Health and education are the basic needs of a common man. In our society, the condition of our hospitals and schools is very miserable. There is a hard need to improve them and it is a responsibility of the present government to take step and fix a high budget for the improvements of these two departments. Instead of this, the main intention of the present government is on "Metro Buses Project". The statement of the Punjab Minister indicates that he knows the real need of the public and he declares his government top priorities that are health and education. The reporter's open eyes and sad face show his seriousness on taking the interview. The Punjab minister frowning' eyes show his irritation on listing the comments from the common man after giving his statement. The Punjab minister's dress shows that he is belonged to politician family. In this image, the man indicates a common person. His open eyes show his tiresome and exhaust by facing the problems of the basic facilities. The man's closed lips show his sadness and silence on the problems of the basic needs. His open hands express his upset mind and questioning which he wants to ask against the present government. His half naked and skinny body reveals that he is the victim of lack of basic necessities. The man's short beard indicates that he is neglected by the government in the society. The caption "...If left something from Metro buses" expresses his question from the Punjab minister after his statement that he is to be sure about his statement or not. This image is a social satire on the present government to give a main focus on traveling and roads facilities and neglects the basic facilities of health and education. 


\section{Conclusion}

The present research was a semiotic analysis of cartoons published in Pakistani English newspapers. The objectives of the research were to identify the recurring social themes in cartoons, to investigate the semiotic devices used in cartoons, and to find out the logical connection between linguistic and semiotic devices in cartoons for the reflection of social issues in Pakistani English newspapers. After analysis, it was found that the newspaper's cartoonists used specific linguistic devices like exaggeration, symbolism, labeling, caption, irony and analogy for construction of social satire in cartoons. They also exposed the social issues like corruption, inflation, explanation, terrorism, poor democracy, wrong policies of the government, thana culture, energy crises, meat adulteration and child brutality. There were also logical connections between linguistic and semiotic devices in cartoons to enhance the reader's understanding of social satire. The analysis of the research shows that social issues of the society and politicians are the subjects of cartoons in newspapers. So, the semiotic discourses like cartoons are very powerful means in shaping people's perceptions. They have two-fold appeals. On one hand, they amuse us and on the other, provide us a current social commentary on the issues around us. The current research will open a new window for the future researcher to conduct research in these similar areas. The study also will pave the way of young language learners to conduct research on social satire to explore more realities in form newspaper cartoons.

\section{References}

[1] Crime nexus[cartoon].(2015, August10). Daily Times. Retrieved from http://www.dailytimes.com.pk/

[2] Development[cartoon].(2015, November 02 ). Dawn. Retrieved from http://www.dawn.com/

[3] Eco, U. (1976). A theory of semiotics. Bloomington: Indian University Press.

[4] Eden, M. (2010). Understanding the world of political cartoons. Netherland: Royal Netherland Publications.

[5] Edwards, J. L., \& Ware, L. (2005). Representing the public in campaign media: A political cartoon perspective. American Behavioral Scientist, 49(3), 466-478.

[6] Fairclough, N. (1998). Political discourse in the media: An analytical framework. Approaches to media discourse. Oxford: Blackwell, 142-162.

[7] Goldstein, M. C. (1982). Lhasa street songs: Political and social satire in traditional Tibet. The Tibet Journal, 7(1/2), 56-66.

[8] Govt hospitals in 10 districts to be privitised [cartoon].(2015, June 21). Daily Times. Retrieved from http://www.dailytimes.com.pk/

[9] Greenberg, L. S. (2002). Emotion-focused therapy: Coaching clients to work through their feelings. American Psychological Association.

[10] Mazid, B. E. M. (2008). Cowboy and misanthrope: A critical discourse analysis of Bush and Bin Ladin cartoons. Discourse \& Communication, 26.

[11] iiiPress, C. (1981). The political cartoon. Fairleigh Dickinson University Press.

[12] Price hike [cartoon].(2015, September 05 ). Daily Times. Retrieved from http://www.dailytimes.com.pk/

[13] Private education [cartoon].(2015,September 02). Dawn. Retrieved from http:www.dawn.com/

[14] Ramzan mubarik[cartoon].(2016, June 07). Daily Times. Retrieved from http://www.dailytimes.com.pk/

[15] Ramzan[cartoon].(2014, June 28). Daily Times. Retrieved from http://www.dailytimes.com.pk/

[16] Run from Lahore run for your life [cartoon].(2015, September 04 ). Daily Times. Retrieved from http://www.dailytimes.com.pk/

[17] Silverman, K. (1983). The subject of semiotics. Oxford University Press.

[18] Soyinka, W. (1963). The Jero's Plays. Methuen Press, London.

[19] Stanly, J. (2006). The comparative study of Ola Rotimi's our husband has gone mad agian and Osofisan's midnight hotel. Journal of Social Sciences \& Humanities, 32-40.

[20] Tahreem, Y. (2013). Organizational cynicism, work related quality of life and organizational commitment in employees. Pakistan Journal of Commerce \& Social Sciences, 9(2), 568-582.

[21] Tehseem, T., \& Bukhari, Z. (2015). Spoiling or the saving faces in Pakistani newspapers: A multimodal discourse perspective on analyzing political cartoons. Asian Journal of Social Sciences, 1-14.

[22] Templin, C. (1999). Hillary Clinton as threat to gender norms: Cartoon images of the first lady. Journal of Communication Inquiry, 23(1), 2036. 